\title{
Vertical Distribution of Pea (Pisum sativum L.) Seed Yield Depending on the Applied Bacterial Inoculants
}

\author{
Zając T. ${ }^{1}$, Klimek-Kopyra A. ${ }^{1}$, Oleksy A. ${ }^{1}$, Lenart A. ${ }^{2}$ \\ ${ }^{1}$ Institute of Plant Production, Agricultural University of Poland \\ ${ }^{2}$ Department of Microbiology, Agricultural University of Poland, Al. Mickiewicza 21, 31-120 Kraków, Poland \\ Correspondence: Klimek-Kopyra A., Instytut of Plant Production, Agricultural Univerity of Poland. E-mail: \\ klimek.a@wp.pl
}

Received: March 2, 2012 Accepted: March 23, 2012 Online Published: December 14, 2012

doi:10.5539/jas.v5n1p260 URL: http://dx.doi.org/10.5539/jas.v5n1p260

The study was supported by NCN (NrNN310 151837)

\begin{abstract}
Among legumes, pea (Pisum sativum L.) is the second most important grain legume crop in the world, which is widely used both in human nutrition and as fodder. The yield potential of cultivars is one of the major factors that determine the use of field pea. Currently, pre-sowing inoculation of pea seeds is a promising treatment and is one of agronomic solutions for sustainable agriculture development. The objective of the research was to estimate the productivity of the 'afila' and 'semileafs' morphotypes of field pea, depending on different inoculants based on symbiotic bacteria (Rhizobium)-commercial $\left(\right.$ Nitragine $\left.^{\mathrm{TM}}\right)$ and noncommercial, produced by the Polish Institute of Soil Science and Plant Cultivation (IUNG). The research was based on the precise field experiment, conducted in four replicates and carried out in the experimental field of Bayer ${ }^{\circledR}$ company located in Modzurów, Silesian viovodeship. The experimental field soil was classified as Umbrisol-slightly degraded chernozem, formed from loess. The examined inoculants were applied during sowing. The presented results of the studies on the symbiotic nitrogen fixation by leguminous plants indicate that the productivity of pea was positively affected by the application of IUNG (noncommercial) inoculant. On the other hand, it is not recommended to use Nitragine ${ }^{\mathrm{TM}}$ separately, as it inhibits the growth of pea. Plants of the 'Klif' variety used the symbiotically fixed nitrogen more effectively and demonstrated higher yield component and better phenotypic parameters.
\end{abstract}

Keywords: pea varieties, nodulation, yield

\section{Introduction}

Grain legumes are widely recognized as a significant source of proteins (Duranti \& Guis, 1997) and have become very important in human and domestic animal nutrition (Cummings et al., 2001). Presently, the increasing interest in low input sustainable agricultural systems on cropping farms, from an economic and environmental viewpoint opens the door for continued interest in grain legumes (White, 1989). Among legumes, pea (Pisum sativum L.) is the second most important grain legume crop in the world, which is widely used in human nutrition and as fodder (Cristou, 1997). The importance of legumes to these purposes is not only due to their nitrogen $(\mathrm{N})$ fixing capabilities but also due to their ability to interrupt the cycles of diseases and pests affecting other crops (Cummings et al., 2001). Many authors claimed that yields could be increased by legume seed inoculation compared to nitrogen fertilizer variants (Dobereiner et al., 1995). Legume inoculation is an established agricultural practice that has been used for more than a century to introduce rhizobia into the soil (Deaker et al., 2004). Inoculants are produced commercially in many countries. Their quality depends on both the number of rhizobia they contain and their effectiveness in fixing $\mathrm{N}$ with the target host (Amarger, 2001). Symbiotic effectiveness is one of the most important factors when selecting an inoculant strain (Stephens \& Rask, 2000). In Brazil, Thies et al. (1991) found that re-inoculation of soybean guaranteed increased crop yield. Inoculants are produced in powdered, granular or liquid forms (Date, 2000; Deaker et al., 2004). They can be applied directly onto seeds, which is the traditional and most commonly used method of inoculation, on mineral granules (Wadoux, 1991). Inoculation of annual crop legumes has produced variable results when different 
inoculation methods were used. Granular seed inoculation gave increased seed yield compared to peat-based seed inoculants in dry peas (Pisum sativum L.) and in chickpea (Cicer arietinum L.) (McKenzie et al., 2001, Kyei-Boahen et al., 2002; Gan et al., 2005). In common bean, the most common method of inoculation is to apply the culture of Rhizobium spp. to seed prior to sowing (Hungria et al., 2003). An alternative method is the application of the inoculant to the soil at the time of sowing. Soil application of the inoculum has been successful in annual legumes; soybean and field pea (Pisum sativum L.) (Danso et al., 1990; McKenzie et al., 2001). Boros and Sawicki (1997) emphasize, that the new high-yielding pea cultivars have high soil and cultivation technology requirements. It may be assumed with high probability level, that pre-sowing inoculation of pea seeds is currently a perspective solution and may be a reasonable agrotechnical option for sustainable agriculture. This research was undertaken because of the potentially high pea productivity in Europe. Its cultivation should be developed, obtaining the best economic efficiency. This study was conducted to evaluate the productivity of two different pea varieties in order to assess the variability of morphological traits and yield components after inoculation with symbiotic bacteria (Rhizobium) using powder $\left(\mathrm{Nitragine}^{\mathrm{TM}}\right)$ and gel inoculant (IUNG).

\section{Material and Methods}

\subsection{Plant Material}

Two genotypes from Polish seed breeding companies were used in the study. The 'Afila' variety of pea 'Tarchalska', created by DANKO company, is used as an edible and fodder crop, while the 'Klif' variety was created by Poznan breeding company and is used only as fodder.

\subsection{Establishment of a Field Experiment}

The plant seeds were sown in the third week of April 2009 and in the second week of April 2010. The research was based on the precise field experiment, conducted in four replicates and carried out in the experimental field of Bayer ${ }^{\circledR}$ company located in Modzurów, Silesian voivodeship. The experimental field soil was Umbrisol-slightly degraded chernozem, formed from loess, classified as good wheat complex and the $2^{\text {nd }}$ bonitation class, therefore the soil conditions were sufficient for the pea needs. The soil $\mathrm{pH}$ was neutral $(\mathrm{pH}$ in 1 $\mathrm{mol} / \mathrm{dm}^{3} \mathrm{KCl}-6.28$ ) and the richness of topsoil layer was high: $19.1 \mathrm{mg} / 100 \mathrm{~g}_{2} \mathrm{O}_{5}, 21.7 \mathrm{mg} / 100 \mathrm{~g} \mathrm{~K}_{2} \mathrm{O}$, and 10.1 $\mathrm{mg} / 100 \mathrm{~g} \mathrm{Mg}$. A randomized system was adopted in the conducted field experiment and it consisted of 4 replicates, and the size of each field was $8.4 \mathrm{~m}^{2}$. The following pre-sowing doses were applied: phosphorus- 48 $\mathrm{kg} \mathrm{ha}^{-1}\left(\mathrm{P}_{2} \mathrm{O}_{5}\right)$ and potassium $-72 \mathrm{~kg} \mathrm{ha}^{-1}\left(\mathrm{~K}_{2} \mathrm{O}\right)$. Ammonium nitrate was applied as a starting dose" $-20 \mathrm{~kg} \mathrm{ha}{ }^{-1} \mathrm{~N}$. One hundred and twenty germinating seeds of 'Afila' variety of pea 'Tarchalska' and one hundred germinating seeds of 'Klif' variety were sown in $1 \mathrm{~m}^{2}$ with a span of $15 \mathrm{~cm}$.

Two inoculants containing Rhizobium leguminosarum bv. viceae were applied during sowing-commercially available, powder Nitragine ${ }^{\mathrm{TM}}$, produced by the BIOFOOD company (Poland) and non-commercial, gel inoculant produced by the Polish Institute of Soil Science and Plant Cultivation (IUNG).

\subsection{Weather Conditions}

Monthly precipitation and average temperature for 2010-2011 growing seasons in Modzurow are presented in Table 1. In 2010 intensive precipitation was observed in the seedling phase (May) and during the flowering phase, which contributed to the growth and development retardation of vegetative and generative stages. This reduced plant density, number of seeds and pods, and consequently resulted in low yield. In 2011 the precipitation and average temperature were optimal for the plant growth.

Table 1. Weather conditions in an experimental site at various pea growth stages at the Modzurów research station during 2010-2011

\begin{tabular}{cccccccc}
\hline Variable & Year & March & April & May & June & July & August \\
\hline \multirow{3}{*}{ Temperature $\left({ }^{\circ} \mathrm{C}\right)$} & 2010 & 4.0 & 7.5 & 11.7 & 16.7 & 20.4 & 18.5 \\
& 2011 & 2.0 & 9.7 & 13.2 & 17.4 & 17.3 & 18.9 \\
& Mean & 3.0 & 8.6 & 12.4 & 17.5 & 13.8 & 18.7 \\
Precipitation $(\mathrm{mm})$ & 2010 & 17.0 & 66.5 & 193.2 & 103.5 & 208.5 & 95.1 \\
& 2011 & 33.1 & 29.2 & 71.5 & 99.5 & 167.5 & 73.2 \\
& Mean & 25.0 & 47.8 & 132.3 & 101.5 & 188.0 & 84.1 \\
\hline
\end{tabular}




\section{Results and Discussion}

\subsection{Phenotypic Parameters and Yield Components of Pea Varieties}

The results of the statistical analyses of the investigated characteristics over two years of the study are presented in Table 2. The comparison between the applied inoculant revealed the lack of significant differences between phenotypic parameters and pea yield components. The results revealed a significant variation of yield components among the pea varieties. The 'Klif' variety showed higher yield components e.g. node number, pod number or seed number in a pod, as well as better morphological traits i.e. position of the first reproductive node in a shoot or total length of shoot. Moreover, the results varied in years. Weather conditions in 2010 were more favorable for the growth and development of morphological traits of pea, whereas for the formation of yield components-in 2011. The 'Tarchalska' variety showed the tendency to reduce the position of the first reproductive node on a shoot after inoculations applied in both growing seasons. On the contrary, after application of IUNG inoculant, the 'Klif' variety showed higher parameters of yield components, e.g. number of pods per node, number of seeds and pods, which were particularly evident in 2011, whose climate was more favorable for the plant growth. Moreover, in the same conditions, the 'Klif' variety obtained the highest total shoot weight. Similar tendency was observed for seed yield per plant. Similar results were found by Santalla et al (2001), who observed significant differences in morphological traits, e.g. weight and length of plant parts among pea varieties. They indicated, that pea varieties showed a significant variety-strain interaction after Rhizobium inoculation.

Huang and Erickson (2007) indicated that Rhizobium inoculation leads to simultaneous changes of many morphological features, and positively affects seed yield. On the contrary, Yadav (2010) observed the lack of significant differences in morphological parameters after application of inoculant. Nevertheless, he observed significant differences between yield components of the studied pea genotypes. Higher number of pods and seeds in a pod, and higher weight was observed after inoculation. The findings of this study are however not consistent with the results obtained by Strzelec (1988) and Pytlarz-Kozicka (2010), who observed that the inoculated plants are more vigorous and bloom a few days later. After application of the inoculant we noticed, that morphological features were similar between varieties.

Table 2. Phenotypic parameters of pea varieties

\begin{tabular}{|c|c|c|c|c|c|c|c|c|}
\hline \multirow[b]{2}{*}{ Obiect, Years } & \multirow{2}{*}{$\begin{array}{c}\text { Weight of seeds } \\
\text { per plant }[\mathrm{g}]\end{array}$} & \multicolumn{3}{|c|}{ Number of $\left[n_{0}\right]$} & \multicolumn{2}{|c|}{ Heigth of $[\mathrm{cm}]$} & \multirow{2}{*}{$\begin{array}{l}\text { Total shoot } \\
\text { Length }[\mathrm{cm}]\end{array}$} & \multirow{2}{*}{$\begin{array}{l}\text { Weigth of } \\
\text { shoot }[\mathrm{g}]\end{array}$} \\
\hline & & Nodes & Pods & Seeds & $\begin{array}{c}1^{\text {st }} \text { reproductive node } \\
\text { in a shoot }\end{array}$ & $\begin{array}{l}\text { reproductive } \\
\text { shoot }\end{array}$ & & \\
\hline Control- uninoculated & 7.23 & 4.0 & 7.8 & 29.2 & 63.5 & 20.9 & 84.4 & 11.7 \\
\hline Nitragine $^{\mathrm{TM}}$ & 7.34 & 3.8 & 7.6 & 29.3 & 61.3 & 19.9 & 81.2 & 11.9 \\
\hline IUNG inoculum & 8.18 & 4.1 & 8.0 & 30.6 & 60.3 & 20.6 & 80.8 & 12.5 \\
\hline $\operatorname{LSD}_{0.05}$ & n.s. & n.s. & n.s. & n.s. & n.s. & n.s. & n.s. & n.s. \\
\hline cv. 'Tarchalska' & 7.39 & 3.6 & 7.4 & 26.5 & 58.3 & 19.6 & 77.9 & 11.5 \\
\hline cv. 'Klif' & 7.77 & 4.3 & 8.2 & 32.9 & 65.0 & 21.3 & 86.4 & 12.6 \\
\hline $\operatorname{LSD}_{0.05}$ & n.s. & 0.33 & 0.62 & 3.13 & 2.31 & n.s. & 2.99 & n.s. \\
\hline 2010 & 5.98 & 4.0 & 7.6 & 26.6 & 60.3 & 23.1 & 83.4 & 10.1 \\
\hline 2011 & 9.19 & 4.0 & 8.0 & 32.8 & 63.1 & 17.8 & 80.8 & 13.9 \\
\hline $\operatorname{LSD}_{0.05}$ & 0.87 & n.s. & n.s. & 3.13 & 2.31 & 2.36 & n.s. & 1.24 \\
\hline
\end{tabular}

\subsection{Grain Yield Components}

The analyses of variance were carried out in order to determine the effect of inoculation and pea varieties on yield components (Table 3). Seed and protein yield of pea was not significantly different after inoculant application, however a significant difference was observed in the plant density. Significantly less plants per square meter were observed after the application of IUNG inoculant. These results are consistent with the results obtained by Pytlarz-Kozicka (2010). The author obtained higher densities of lupine after Nitragine ${ }^{\mathrm{TM}}$ application, 
which resulted in higher seed yield. However, the position of the first pod, number of pods and number of seeds per pod were not varied.

Table 3. Grain yield components of the examined genotypes and applied inoculants

\begin{tabular}{|c|c|c|c|c|}
\hline Treatments & $\begin{array}{c}\text { Seed Yield } \\
{\left[\mathrm{dt} \times \mathrm{ha}^{-1}\right]}\end{array}$ & Density $\left[\right.$ pcs. $\left.\times \mathrm{m}^{-2}\right]$ & Protein content $[\%]$ & $\begin{array}{c}\text { Protein yield } \\
{\left[\mathrm{kg} . \times \mathrm{ha}^{-1}\right]}\end{array}$ \\
\hline Control- uninoculated & 40.6 & 67.7 & 22.8 & 772.3 \\
\hline Nitragine $^{1 \mathrm{M}}$ & 41.3 & 65.7 & 22.9 & 790.1 \\
\hline IUNG inoculum & 42.3 & 59.8 & 23.3 & 817.3 \\
\hline $\operatorname{LSD}_{0.05}$ & n.s. & 5.09 & n.s. & n.s. \\
\hline cv. 'Tarchalcka' & 37.6 & 63.1 & 23.6 & 743.1 \\
\hline cv. 'Klif' & 45.2 & 65.6 & 22.3 & 843.4 \\
\hline $\operatorname{LSD}_{0.05}$ & 2.25 & n.s. & 0.38 & 41.47 \\
\hline 2010 & 31.6 & 63.1 & 24.5 & 656.0 \\
\hline 2011 & 51.2 & 65.7 & 21.4 & 930.4 \\
\hline $\operatorname{LSD}_{0.05}$ & 2.25 & n.s. & 0.38 & 41.47 \\
\hline
\end{tabular}
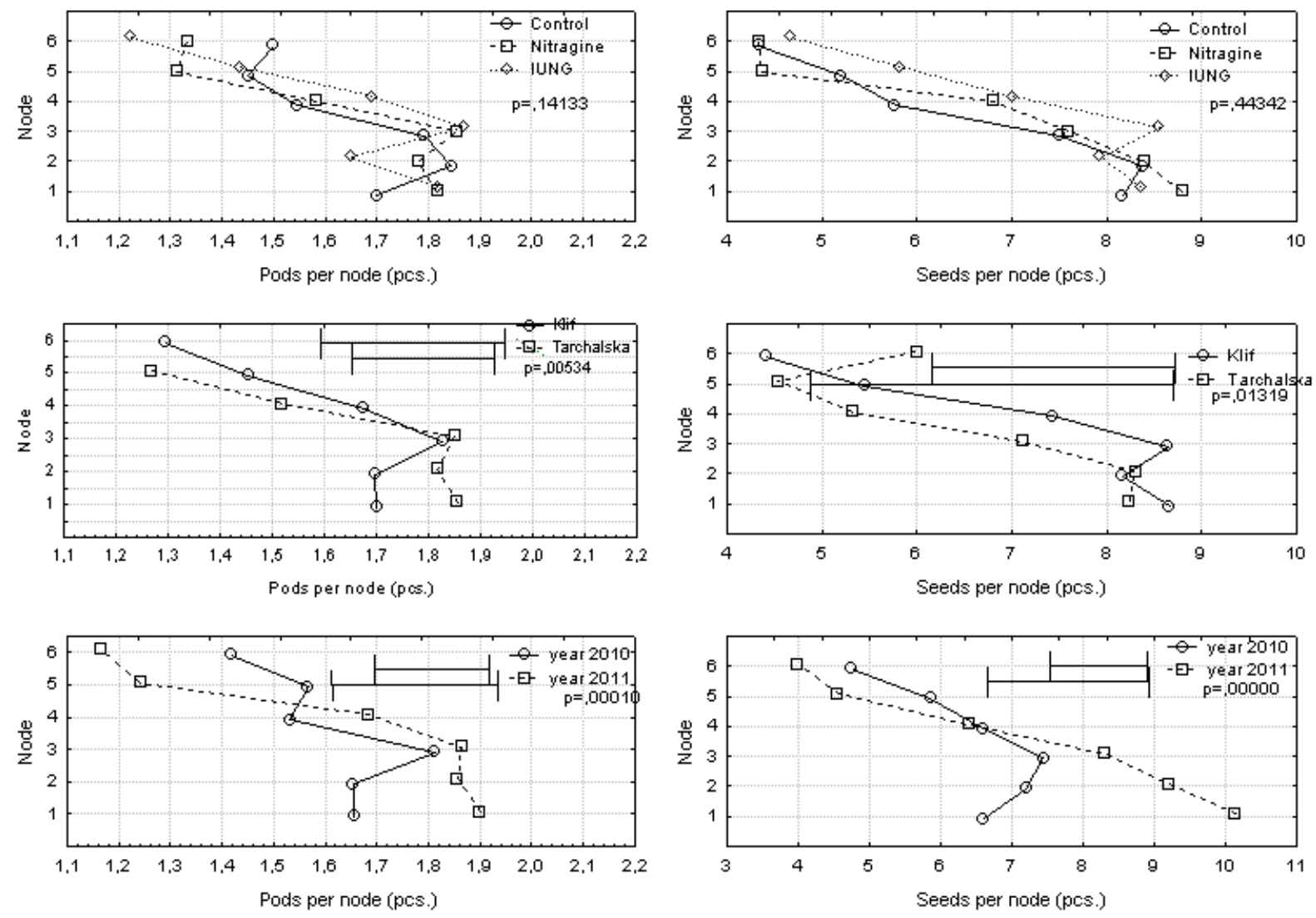

Figure 1. Vertical distribution of pods and seeds at consecutive nodes in the developing pea plant

The yield components and protein yield exhibited varying trends of association among pea varieties. The seed and protein yield was significantly higher in the 'Klif' variety in 2011, while the protein content in pea seeds was higher in 2010. Karahne and Singh (2009) comparing 8 pea genotypes and 3 levels of rhizobial inoculation for two consecutive years, obtained significant differences between the studied treatments. Inoculation with Rhizobium leguminosarum made the plants taller and enhanced biomass production through branching, but delayed their maturity. It resulted in more pods, enlarging them to contain more seeds, leading to higher test weight and enhanced harvest index. 


\subsection{Vertical Distribution of Pods and Seeds at Consecutive Nodes}

Vertical distribution of pods and seeds at consecutive nodes is presented in Figure 1. The number of pods and seeds slightly decreased with increasing subsequent productive nodes. The application of inoculant resulted in higher yield production. Regardless of the inoculant form, the pea plants formed pods in each of the node. Higher amount of pods and seeds was obtained after IUNG inoculant's application. A comparative analysis of pea varieties indicated some differences. Higher number of nodes and seeds, but lower pod number was observed for the 'Klif' variety. Contrary effects were noticed in the 'Tarchalska' variety. According to French (1990), pods that were formed earlier in the reproductive phase contributed much more to the total seed yield than those formed later. This was due to later-formed pods containing fewer seeds and being more likely than early-formed pods to abscise before reaching maturity. The proportion of total seed yield carried on the first three reproductive nodes varied from $64.3-94.2 \%$.

Moreover, an amount of pods per plant differed in years. Higher number of pods per node and seeds per pods was observed in 2011, despite the fact that the studied pea varieties developed similar reproductive nodes on a shoot. In a harsh growing season (2010) all generative features of pea varieties developed faintly. French (1990) suggested that in short growing season, increased pod formation rates are desirable to allow compression of the pod formation period, so that fewer pods will be formed later in the reproductive phase when the environment is most limiting.

Vertical distribution of seed number and weight of seeds at consecutive nodes is presented in Figure 2. The number and weight of seeds were determined by the pea variety and to a lesser extent by the applied inoculant. Better results of seed parameters were obtained after the application of IUNG inoculant, than after the application of Nitragine ${ }^{\mathrm{TM}}$. These results are consistent with the results obtained by Erman et al. (2009). The application of inoculant had a significant effect on the plant height, number of nodules, shoot dry weight, number of pods, seed yield or biomass yield. The highest values regarding these parameters were obtained from the inoculated plants, whereas the lowest values were obtained from the uninoculated plants.
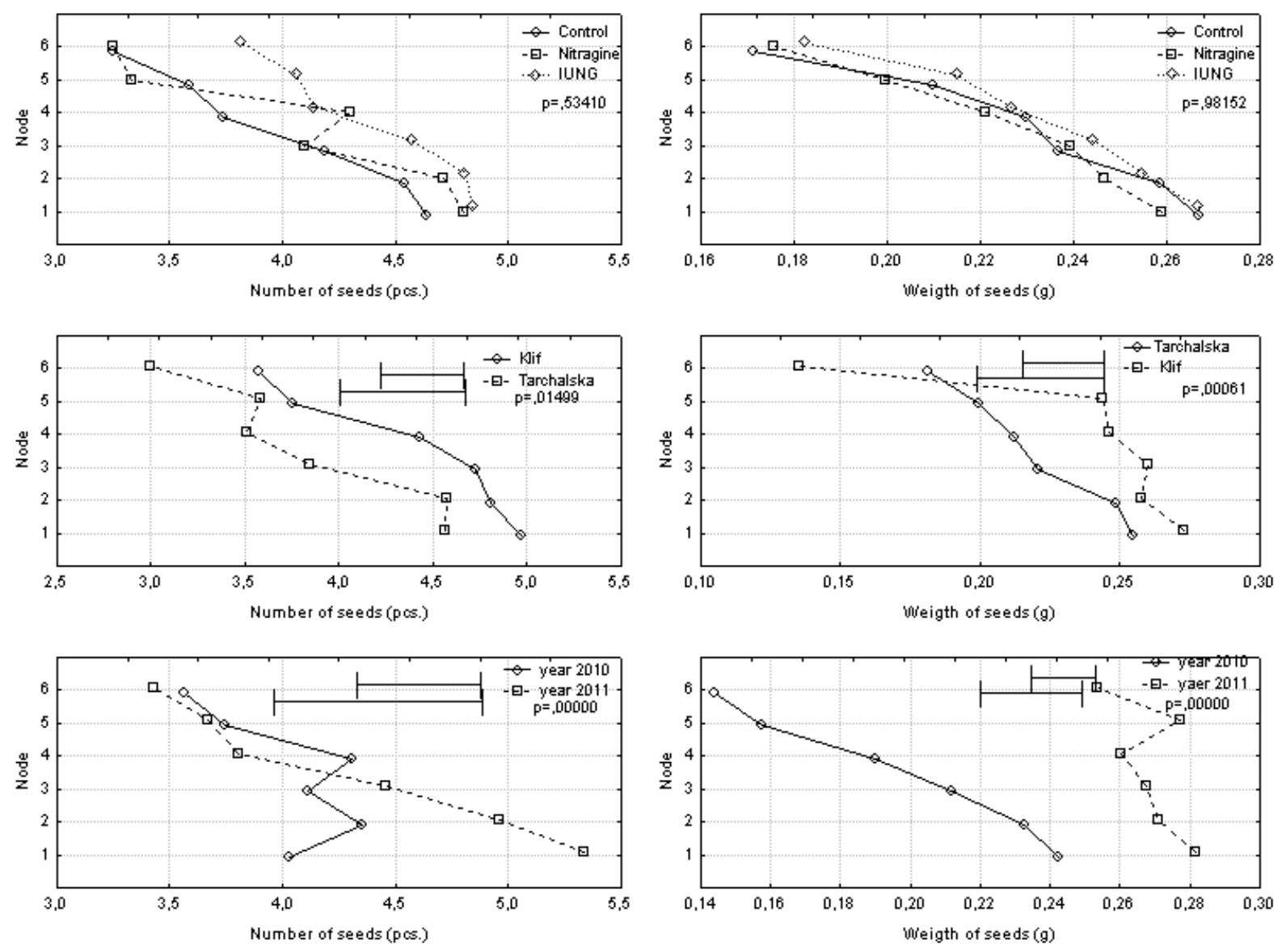

Figure 2. Vertical distribution of numbers and weight of seeds at consecutive nodes in the developing pea plant 
The number and weight of seeds and their vertical distribution on shoots varied between the analyzed pea varieties. The 'Klif' variety produced large amount of seeds in the first three nodes, while the weight of seeds was lower. On the other hand, the 'Tarchalska' variety produced large amount of heavier seeds in the first two reproductive nodes. Moreover, the morphological traits varied in years. More favorable conditions for seed development were observed in 2011. Nevertheless, we observed no differences between the amount of nodes, while the number and the weight of seeds, as well as their position on a shoot were significantly different. The seeds were located mainly on the bottom part of a plant in the first three nodes. Similar findings have been reported by Jeuffry and Devienne (1995). They noticed that the larger amount of assimilates was received by the first three nodes. In that case, nodes produced earlier received larger amount of assimilates - they received better nutrition and had more favorable conditions. The effect of a pod location on a plant and seed position inside the pods on certain characteristics of dry and stewed faba beans were studied by Ziena et al. (1984). The analysis of variance showed that the weight and volume of 1000 dry seeds were significantly affected by the pod location and the seed position. Higher values were obtained for lower pods and terminal and middle seeds. Seeds from upper pods had the highest percentage of seed coat. Pod location showed a significant effect on the weight, volume, $\mathrm{pH}$, soluble and insoluble solids of stewed liquor. No significant effect was found for the pod location or seed positions on the characteristics of stewed beans, except the hydration coefficient which was significantly affected by the pod location.

\subsection{Biometrical Parameters of Pods Depending on a Consecutive Node}

Biometrical parameters of pods and seeds depending on the experimental factors are presented in Table 4. The results revealed considerable differences between the biometrical components of pea and a slight diversity between the applied inoculant. However, on the third and fourth productive node we observed significantly better pod parameters after the application of IUNG inoculant.

Table 4. Biometrical parameters of pods and seeds depending on experimental factors

\begin{tabular}{|c|c|c|c|c|c|c|c|c|c|c|c|}
\hline \multirow{2}{*}{ Item } & \multirow{2}{*}{$\begin{array}{l}\text { No. of } \\
\text { node }\end{array}$} & \multicolumn{3}{|c|}{ Inoculant } & \multirow{2}{*}{$\operatorname{LSD}_{0.05}$} & \multicolumn{2}{|c|}{ Cultivars } & & \multicolumn{2}{|c|}{ Years } & \multirow{2}{*}{$\operatorname{LSD}_{0.05}$} \\
\hline & & Control & Nitragine & IUNG & & Tarchalska & Klif & & 2010 & 2011 & \\
\hline \multirow{6}{*}{ 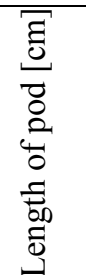 } & 1 & 6.38 & 6.33 & 6.34 & n.s. & 6.30 & 6.40 & n.s. & 6.29 & 6.40 & n.s. \\
\hline & 2 & 6.21 & 5.97 & 6.08 & n.s. & 5.96 & 6.22 & 0.20 & 6.12 & 6.06 & n.s. \\
\hline & 3 & 5.52 & 5.37 & 5.82 & 0.24 & 5.26 & 5.87 & 0.19 & 5.63 & 5.51 & n.s. \\
\hline & 4 & 5.04 & 5.28 & 5.33 & n.s. & 4.72 & 5.57 & 0.28 & 5.39 & 5.05 & 0.27 \\
\hline & 5 & 5.02 & 4.64 & 5.39 & n.s. & 4.45 & 5.25 & 0.50 & 5.01 & 5.15 & n.s. \\
\hline & 6 & 4.59 & 4.80 & 5.04 & n.s. & 3.95 & 4.91 & n.s. & 4.75 & 5.01 & n.s. \\
\hline \multirow{6}{*}{ 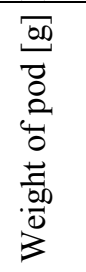 } & 1 & 1.49 & 1.47 & 1.50 & n.s. & 1.53 & 1.44 & 0.088 & 1.17 & 1.76 & 0.088 \\
\hline & 2 & 1.43 & 1.37 & 1.45 & n.s. & 1.41 & 1.42 & n.s. & 1.22 & 1.58 & 0.107 \\
\hline & 3 & 1.20 & 1.18 & 1.31 & 0.109 & 1.19 & 1.26 & n.s. & 1.04 & 1.41 & 0.089 \\
\hline & 4 & 1.03 & 1.14 & 1.12 & n.s. & 1.03 & 1.14 & n.s. & 0.98 & 1.20 & 0.116 \\
\hline & 5 & 0.94 & 0.80 & 1.06 & n.s. & 1.02 & 0.93 & n.s. & 0.74 & 1.23 & 0.167 \\
\hline & 6 & 0.67 & 0.70 & 0.86 & n.s. & 0.58 & 0.78 & n.s. & 0.63 & 1.08 & n.s. \\
\hline \multirow{6}{*}{ 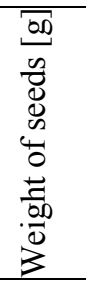 } & 1 & 1.26 & 1.25 & 1.29 & n.s. & 1.26 & 1.27 & n.s. & 0.97 & 1.50 & 0.082 \\
\hline & 2 & 1.20 & 1.16 & 1.24 & n.s. & 1.20 & 1.20 & n.s. & 1.02 & 1.35 & 0.095 \\
\hline & 3 & 1.00 & 0.99 & 1.11 & 0.095 & 1.01 & 1.06 & n.s. & 0.87 & 1.19 & 0.078 \\
\hline & 4 & 0.85 & 0.96 & 0.94 & 0.120 & 0.87 & 0.95 & n.s. & 0.82 & 1.00 & 0.098 \\
\hline & 5 & 0.76 & 0.66 & 0.87 & n.s. & 0.86 & 0.75 & n.s. & 0.60 & 1.01 & 0.144 \\
\hline & 6 & 0.58 & 0.55 & 0.69 & n.s. & 0.40 & 0.65 & n.s. & 0.52 & 0.88 & n.s. \\
\hline \multirow{6}{*}{ 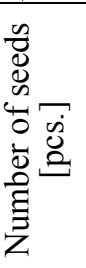 } & 1 & 4.6 & 4.8 & 4.8 & n.s. & 4.6 & 5.0 & 0.28 & 4.0 & 5.3 & 0.28 \\
\hline & 2 & 4.5 & 4.7 & 4.8 & n.s. & 4.6 & 4.8 & n.s. & 4.4 & 5.0 & 0.31 \\
\hline & 3 & 4.2 & 4.1 & 4.6 & 0.35 & 3.8 & 4.7 & 0.28 & 4.1 & 4.5 & 0.28 \\
\hline & 4 & 3.7 & 4.3 & 4.1 & 0.42 & 3.5 & 4.4 & 0.35 & 4.3 & 3.8 & 0.34 \\
\hline & 5 & 3.6 & 3.3 & 4.1 & n.s. & 3.6 & 3.8 & n.s. & 3.7 & 3.7 & n.s. \\
\hline & 6 & 3.3 & 3.3 & 3.8 & n.s. & 3.0 & 3.6 & n.s. & 3.6 & 3.4 & n.s. \\
\hline
\end{tabular}

*, ** Significant at 0.05 and 0.01 probability levels, respectively; NS, non significant 
Longer pea pods were located on the two first nodes, on the bottom of shoots. The 'Klif' variety produced significantly longer pods throughout the whole productive length of shoots, except the first and the last node. There were no differences in the length of the pods in the years of the study. Varied weather conditions have not influenced the pod length. On the other hand, the weight of pods was strictly affected by the weather conditions and slightly by the applied inoculant. The year 2011 was more favourable for reproductive shoot formation. The bottom part of a reproductive shoot produced larger pods, while the consecutive nodes produced smaller pods. Weight of pods was similar in the examined pea varieties, however slightly greater weight was observed in the 'Klif' variety. Pods formed earlier in the reproductive phase contributed much more to the total seed yield than those formed later. This was due to later-formed pods containing fewer seeds and being more likely than early-formed pods to abscise before reaching maturity. The proportion of total seed yield carried on the first three reproductive nodes varied from $64.3-94.2 \%$. This proportion was higher in harsher environments. It is suggested that in short growing seasons increased pod formation rates are desirable to allow compression of the pod formation period, so that fewer pods will be formed later in the reproductive phase when the environment is most limiting (French, 1990).

Weight of seeds as well as weight of shoots were determined by the weather conditions and, to a lesser extent, by the applied inoculant and the variety selection. The 2011 was more favorable for the increase of seed weight. The application of IUNG inoculant resulted in rapid growth of pod and seed weight on the bottom part of reproductive shoots but the weight of seeds and pods decreased in consecutive nodes.

The number of seeds was determined by the type of inoculant and the variety selection. More seeds were produced on the bottom of reproductive shoots. Plants treated with IUNG inoculant gave better results than the uninoculated control. The 'Klif' variety was more productive, as evidenced by the increased number of seeds at consecutive nodes. The number of seeds was determined also by environmental conditions and the number of seeds varied in years of the study. The results indicated that the year 2011 was more favorable for the formation of the first three nodes, while 2010 turned out to be more favourable for consecutive nodes. Jeuffry and Devienne (1995) presented a node hierarchy on the reproductive shoot. The highest nodes on the stem always have fewer assimilates compared to the first one. This is due to competition between all the pods, the pods located on the first nodes having a higher sink strength than those located on the last nodes of the stem. If filling pods had priority, the pods on the highest nodes would have received a lower amount of assimilates than the ones formed earlier. The first nodes may receive less assimilates than those located just above them (Jeuffroy \& Devienne, 1995). If assimilates are allocated to the pods of the same node, as Flinn and Pate (1970) proposed, the first pods would receive larger amount of assimilates.

\section{Conclusions}

The present study revealed the lack of significant differences between phenotypic parameters and pea yield components influenced by the applied two inoculants. The results revealed considerable variation in the yield components among the pea varieties. The 'Klif' variety produced higher yield components, e.g. node number, pod number, seed number in a pod as well as better morphological traits e.g. position of the first reproductive node in a shoot or total length of shoot. Weather conditions in 2010 were more favorable for the growth and development of morphological traits of pea, whereas the formation of yield components was better promoted in 2011.

Biometrical parameters of pods and seeds revealed considerable differences between the pea varieties. The 'Klif' variety was more productive, as evidenced by the number of seeds at consecutive nodes. Number of seeds, weight of seeds and vertical distribution on the reproductive shoot varied between the analyzed pea varieties. The 'Klif' variety produced large amount of seeds in the first three nodes, while the weight of seeds was lower. On the other hand, the 'Tarchalska' variety produced large amount of heavier seeds in the first two reproductive nodes. Application of IUNG inoculant resulted in a rapid increase in the number of pods and seed weight on the bottom part of reproductive shoots but the weight of seeds and pods decreased at consecutive nodes.

\section{References}

Amarger, N., Macheret, V., \& Laguerre, G. (1997). Rhizobium gallicum sp. nov. andRhizobium giardinii sp. nov., from Phaseolus vulgaris nodules. International Journal of Systemic Bacteriology, 47, 996-1006. http://dx.doi.org/10.1099/00207713-47-4-996

Boros, L., \& Sawicki, J. (1997). Evaluation of selected pea (Pisum sativum L.) cultivars and forms. II. Stability of yielding parameters and trait interrelationships. Zesz. Probl. Post. Nauk Rol. z., 446, 107-112. 
Cristou, P. (1997). Biotechnology applied to grain legumes. Field Crops Research, 53, 83-97. http://dx.doi.org/10.1016/S0378-4290(97)00024-5

Cummings, S. P., Humphry, D. R., \& Andrews, M. (2001). A review of the current taxonomy and diversity of symbiotic rhizosphere and bulk soil nitrogen-fixing bacteria, which are beneficial to plants. In Aspects of Applied Biology 63 Plant Microbial Interactions: Positive interactions in relation to crop production and utilization (Vol. 63, pp. 5-18), Wellesbourne, Warwick, UK. Association of Applied Biologists.

Danso, S. K. A., Kapuya, J., \& Hardarson, G. (1990). Nitrogen fixation and growth of soybean as influenced by varying the method of inoculation with Bradyrhizobium japonicum. Plant and Soil, 125, 81-86. http://dx.doi.org/10.1007/BF00010747

Date, R. A. (2000). Inoculated legumes in cropping systems of the tropics. Field Crops Research, 65, 123-136. http://dx.doi.org/10.1016/S0378-4290(99)00082-9

Deaker, R., Roughley, R. J., \& Kennedy, I. R. (2004). Legume seed inoculation technology-a review. Soil Biology and Biochemistry, 36, 1275-1288. http://dx.doi.org/10.1016/j.soilbio.2004.04.009

Deaker, R., Roughley, R. J., \& Kennedy, I. R. (2004). Legume seed inoculation technology-a review. Soil Biology and Biochemistry, 36, 1275-1288. http://dx.doi.org/10.1016/j.soilbio.2004.04.009

Dobereiner, J., Baldani, V. L. D., \& Reis, V. M. (1995). Endophytic occurrence of diazotrophic bacteria in non-leguminous crops. In I. Fendric, M. del Gallo, J. Vanderleyden, M. de Zamaroczy (Eds.), Azospirillum $V I$ and related microorganisms (pp. 3-14). Berlin, Heidelberg: Springer-Verlag. http://dx.doi.org/10.1007/978-3-642-79906-8_1

Duranti, M., \& Guis, C. (1997). Legume seeds: protein content and nutritional value. Field Crops Research, 53, 31-45. http://dx.doi.org/10.1016/S0378-4290(97)00021-X

Erman, M., Ari, E., Togay, Y., \& Cig, F. (2009). Response of Field Pea (Pisum sativum sp. Arvense L.) to Rhizobium Inoculation and nitrogen Application in eastern Anotolia. Jour. Anim. and Vet. Adv., 8(4), 612-616.

French, R. J. (1990). The contribution of pod number to field pea (Pisum sativum L.) yields in a short growing-season environment. Austr. J. Agric.Res., 41(5), 853-862. http://dx.doi.org/10.1071/AR9900853

Gan, Y., Selles, F., Hanson, K. G., Zentner, R. P., McConkey, B. G., \& McDonald, C. L. (2005). Effect of formulation and placement of Mesorhizobium inoculants for chickpea in the semiarid Canadian prairies. Canadian Journal of Plant Science, 85, 555-560. http://dx.doi.org/10.4141/P04-026

Hungria, M., Campos, R. J., \& Mendes, I. C. (2003). Benefits of inoculation of the common bean (Phaseolus vulgaris) crop with efficient and competitive Rhizobium tropici strains. Biology and Fertility of Soils, 39, 88-93. http://dx.doi.org/10.1007/s00374-003-0682-6

Jeuffroy, M. H., \& Devienne, F. (1995). A simulation model for assimilate portioning between pods in pea (Pisum sativum L.) during the period of seed set; validation in field conditions. Field Crops Research, 41, 79-89. http://dx.doi.org/10.1016/0378-4290(95)00002-8

Karahne, V., \& Singh, V. P. (2009). Effect of rhizobial inoculation on growth, yield, nodulation and biochemical characters of vegetable pea (Pisum sativum L.) Act. Agron. Hungarica., 57(1), 47-56. http://dx.doi.org/10.1556/AAgr.57.2009.1.6

Kyei-Boahen, S., Slinkard, A. E., \& Walley, F. L. (2002). Evaluation of rhizobial inoculation method for chickpea. Agronomy Journal, 94, 851-859. http://dx.doi.org/10.2134/agronj2002.0851

McKenzie, B. A. (1989). Navy bean production in Canterbury. In G. D. Hill, \& G. P. Savage (Eds.), Grain Legumes: National Symposium and Workshop. Christchurch: Agronomy Society of New Zealand Special Publication, 7, 97-99.

McKenzie, R. H., Middleton, A. B., Solberg, E. D., DeMulder, J., Flore, N., Clayton, G. W., \& Bremer, E. (2001). Response of pea to rhizobia inoculation and starter nitrogen in Alberta. Canadian Journal of Plant Science, 81, 637-643. http://dx.doi.org/10.4141/P01-006

Pytlarz-Kozicka, M. (2010). Influence of plant protection and nitragine nodulation on healthy and yielding of yellow lupine varieties. Progres of Plant Protection, 50(1), 47-51. 
Santalla, M., Amurrio, J. M., \& de Ron, A. M. (2001). Symbiotic interactions between Rhizobium leguminosarum strains and elite cultivars of Pisum sativum L. Jour. Agron. Crop Sci., 187(1), 59-68. http://dx.doi.org/10.1046/j.1439-037X.2001.00502.x

Stephens, J. G. H., \& Rask, H. M. (2000). Inoculant production and formulation. Field Crops Research, 65, 249-258. http://dx.doi.org/10.1016/S0378-4290(99)00090-8

Strzelec, A. (1988). Symbiotyczne wiązanie N2. Znaczenie bakterii symbiotycznych, ich występowanie w glebie i szczepionki Rhizobium dla roślin motylkowych. Post. Nauk Rol., 4, 17-29.

Thies, J. E., Singleton, P. W., \& Bohlool, B. B. (1991). Influence of the size of indigenous rhizobial populations on establishment and symbiotic performance of introduced rhizobia on field-grown legumes. Applied and Environmental Microbiology, 57, 19-28.

Wadoux, P. (1991). Inoculant production in industry using sterile carriers. In V. A. thomson (Ed.), Expert Consultation on Legume Inoculant Production and Use. Rome: FAO.

White, J. G. H. (1989). Grain legumes in sustainable cropping systems: a review. Lincoln: Agronomy Society of New Zealand Special Publication, 7, 109-115.

Ziena, H. M., Shehata, A. M. T., Youssef, M. M. (1984). The effect of pod and seed positions on the physical and cooking properties of faba beans (Vicia faba). Jour. of the Sci. Food and Agriculture, 35(2), $207-211$. http://dx.doi.org/10.1002/jsfa.2740350212 